\title{
Patterns of Antibody Response of Children with Infections of the Urinary Tract
}

\author{
E. Neter ${ }^{[44]}$, O.R. Oberkircher, M. I.Rubin, J. M. Steinhart and I. Krzeska \\ Departments of Pediatrics and Microbiology, State University of New York at Buffalo, \\ School of Medicine, and Children's Hospital, Buffalo, New York, USA
}

\begin{abstract}
Extract
An immunologic study was carried out on 140 children with infections of the urinary tract. The diagnosis was based on clinical, roentgenologic, urologic, and bacteriologic findings. Of the patients, $37(26 \%)$ had acute infection and the remainder (103 children, $74 \%)$ had chronic or recurrent infection. The hemagglutination test was used to measure the antibody levels against the $\mathrm{O}$ antigens of the urinary isolates. The patients were studied for a period of 1-7 years.

An antibody response was documented in all but $10.7 \%$ of the subjects. Multiple antibody responses occurred in $55 \%$ and single antibody responses in $34.3 \%$ of the patients. There was no significant difference in the antibody responses to commonly encountered serogroups of Escherichia coli and other bacteria less frequently found in urinary tract infection. In 17 subjects, the antibody titer decreased rapidly within 2-8 weeks, and in 9 subjects reinfection with the microorganisms of identical serogroups led to a recall antibody response. It was shown that in 14 subjects $(10 \%)$, minimal bacteriuria was accompanied by the production of the corresponding $O$ antibodies, and in an additional 7 subjects $(5 \%)$, asymptomatic bacteriuria, following or preceding overt infection, led to a specific antibody response.

Continued production of $\mathrm{O}$ antibodies over many months was observed following overt infection even in the absence of persisting bacteriuria; in other patients, however, even prolonged bacteriuria resulting from identical serogroups was not associated with the production of the corresponding $\mathrm{O}$ antibodies.

It is suggested that determination of the immune response of patients with urinary tract infection may aid in the identification of the etiologic role of urinary isolates, even when present in small numbers; may document infection by two or more antigenically unrelated microorganisms; and may help in the differentiation of relapse and reinfection. Thus, determination of the immune response may be a useful tool in the elucidation of certain aspects of this frequent, but incompletely understood disease.
\end{abstract}

\section{Speculation}

Because infectious agents or their antigens must reach cells of the immune apparatus to elicit an antibody response, documentation of the production of specific antibodies may aid in the differentiation between true infection and urinary contamination, between reinfection and relapse, and in ascertaining the clinical signification of minimal bacteriuria. It may be speculated that since titers of $\mathrm{O}$ antibodies decrease substantially a few months after recovery from shigellosis and salmonellosis, persistent elevated antibody titers against $\mathrm{O}$ antigens of urinary pathogens are associated with continued antigenic stimulation and may reflect continuation of the pathologic processes. 


\section{Introduction}

Determination of a specific immune response to an infectious agent has been used as a diagnostic tool for more than half a century. Documentation of an increase in serum antibody is of value in evaluating the etiological role of suspected bacteria, as was done with certain serogroups of Escherichia coli as enteropathogens [27]. This approach may provide evidence for the etiologic role when the pathogen is no longer present in the patient. In addition, it provides information to identify onset of infection, elucidates the role of pathogens in suspected mixed infections, and is of aid in epidemiologic studies. Documentation of the immune response also offers opportunities for the study of urinary tract infection. As early as 1898, PfaundLer [31] described the development of agglutinins in children with this infection. Only recently has this approach been utilized with modern techniques. The passive hemagglutination test was shown to be a sensitive and specific procedure for the titration of $\mathrm{O}$ antibodies against various enteric bacteria $[20,22]$. These antibodies are directed against the endotoxic lipopolysaccharides present in the cell walls, also referred to as somatic or $\mathrm{O}$ antigens. A comprehensive study of urinary tract infections in children has been in progress in the Departement of Pediatrics for more than a decade. As a result of investigations, several patterns of antibody responses have been observed and are the subject of this report.

\section{Materials and Methods}

Subjects

One hundred and forty patients ( 125 females and 15 males) were enrolled in the Pyelonephritis Clinic of the Department of Pediatrics. The clinical, bacteriologic, and immunologic studies were completed and extended for a period of at least 1 year [43]. The subjects ranged in age from 1 month to 16 years. These patients do not represent an unbiased sample of individuals with urinary tract infection; individuals with chronic and recurrent infections are more frequently referred than patients with effectively treated acute infections or subjects with asymptomatic bacteriuria. In addition, follow-up of these patients over many months may have resulted in the recognition of otherwise undetected recurrent infection. Only $37(26 \%)$ subjects had acute infection. A definitive diagnosis of urinary tract infection was based on clinical, roentgenologic, urologic, and bacteriologic findings. Two 'clean catch' samples, followed in case of doubt by a catherized or suprapubically aspirated urine specimen, were obtained for bacteriologic examination.

Bacteriologic examination of urine was performed within $2 \mathrm{~h}$ after procurement of the specimens and included identification of microorganisms by conventional methods as well as quantitation. For the latter procedure pour plates were prepared with $1 \mathrm{ml}$ of aseptically obtained urine and with $1 \mathrm{ml}$ of urine in a dilution of $1: 1,000$. This method provided information of a range of $1-10^{6}$ colonies $/ \mathrm{ml}$. Serotyping was performed on all isolates of E.coli according to the methods of EDWARDs and EWING [8], with O antisera provided by the National Communicable Disease Center [43]. Blood specimens were obtained monthly during year 1 and if infection continued or recurred sampling was continued. After recovery, blood specimens were obtained three or four times a year. The sera were kept frozen at $-20^{\circ}$. Freezing and thawing did not result in a significant loss of antibody activity. Determination of the $\mathrm{O}$ antibody response was accomplished by the passive hemagglutination test $[23,26]$. Antigens were prepared from all urinary isolates of gram-negative bacteria from each patient. Agar-grown cultures were suspended in phosphate buffer, heated for $1 \mathrm{~h}$ at $100^{\circ}$, and centrifuged at $23,500 \times g$. The supernates, containing the $\mathrm{O}$ antigens, were kept frozen at $-20^{\circ}$. In addition, for control purposes, antigens from five serogroups each of Salmonella, Shigella, and enteropathogenic E.coli were utilized. Twofold serial dilutions of serum $(0.2 \mathrm{ml})$ were mixed with common enterobacterial antigen from $E$. coli $\mathrm{O} 14(0.2 \mathrm{ml})$ to remove antibodies to the latter antigen [16]. The mixtures were incubated at $37^{\circ}$ for $30 \mathrm{~min}$. Erythrocytes modified with $\mathrm{O}$ antigens of the isolates and of the control antigens $(0.2 \mathrm{ml})$ were then added, and the mixtures were again incubated for $30 \mathrm{~min}$ at $37^{\circ}$. The resulting hemagglutination, utilizing human group $\mathrm{O}$ erythrocytes, was read grossly after centrifugation at $1,300 \times g$ for $2 \mathrm{~min}$. All tests on a given patient were performed simultaneously, using all serum specimens and all antigens from the individual. Titers are expressed as the reciprocal of the highest dilution yielding visible hemagglutination. The antibody response was considered to be significant if the antibody titer increased or decreased at least fourfold in the absence of a similar change in the titers of antibodies against other isolates from the patients and/or against the control antigens of Salmonella, Shigella, and enteropathogenic E.coli. In the vast majority of patients with $E$.coli infection the specificity of the $\mathrm{O}$ antibodies in the serum corresponded to the $O$ serogroups of the isolates.

\section{Results}

The study of the antibody response of 140 children with documented urinary tract infection revealed several antibody response patterns: 1) presence or absence of 
antibody response; 2) single and multiple antibody responses; 3 ) antibody responses of short or long duration; 4) recall antibody response; 5) minimal bacteriuria, following or preceding overt disease, with antibody response; and 6) asymptomatic bacteriuria with antibody response.

Since certain serogroups of E.coli account for approximately $40-60 \%$ of all urinary tract infections due to this microorganism [21], the data on the immune responses of the patients are presented in three categories: 1) E. coli serogroups frequently encountered in urinary tract infections $(\mathrm{O} 1, \mathrm{O} 2, \mathrm{O} 4, \mathrm{O} 6, \mathrm{O} 7, \mathrm{O} 11$, O 15, O62, and O 75), (UP); 2) E. coli serogroups less commonly found in urinary tract infection (NUP); and 3) other gram-negative bacteria including nongroupable E.coli as well as the Enterobacter, Klebsiella, Pseudomonas, and Proteus (others).

A summary of the pertinent findings on the $\mathrm{O}$ antibody response of 140 children with urinary tract infection is presented in table $\mathrm{I}$.

The term 'immune episode' is employed to denote the occurrence of a significant antibody response. The occurrence of two or more independent antibody responses in a single subject, separated by weeks or months, is referred to as 'multiple immune episodes'. Since many patients developed antibodies against two or more antigenically unrelated species or serogroups of microorganisms, the number of immune episodes exceeds that of subjects.

\section{Frequency of the Antibody Response}

Study of the antibody response of the 140 patients revealed that a significant increase in the titer of homologous antibodies occurred in $125(89.3 \%)$. This high rate of antibody response probably was related to the fact that the majority of children suffered from chronic or recurrent infection and that antibody responses were measured at frequent intervals with antigens prepared from all urinary isolates. Thus, 77 of 140 patients had 202 immune episodes. In subjects with antibody response, it was noted that commonly encountered serogroups of E.coli (UP) accounted for 78 episodes and less commonly found serogroups (NUP) for 70 episodes of all infections due to typable E.coli. Antibody response to the most commonly encountered serogroups of E.coli are summarized in table II. It can be seen that antibodies were produced by almost all patients (89-100\%) against serogroups $\mathrm{O} 1$ and $\mathrm{O} 7$ belonging to UP and against O8 belonging to NUP. Among 148 episodes associated with typable E.coli strains, 78 or $52.7 \%$ were related to serogroups belonging to the UP group. This finding is in accord with previously reported bacteriologic observation that UP serogroups account for approximately $40-60 \%$ of $E$. coli urinary tract infection [21]. Only 15 patients failed to reveal a specific antibody response, for a total of 19 episodes; the urinary isolates in the majority $(57.9 \%$ ) belonged to the UP group and only $15.8 \%$ to the NUP group. Failure to produce antibodies against the urinary isolates was not due to impairment of the immunologic apparatus, for three of these patients produced both $\mathrm{H}$ and $\mathrm{O}$ antibodies following immunization with typhoid vaccine.

\section{Single versus Multiple Antibody Responses}

Based on bacteriologic and immunologic data, it has been shown that children with chronic and recurrent infection of the urinary tract frequently harbor different microorganisms at different times. It was not unexpected, therefore, that such patients responded to infection with production of antibodies with different specificities. In the present series of 125 patients with significant antibody responses, $48(34.3 \%)$ produced antibodies against a single isolate and $77(55 \%)$ against two or more isolates at different times. No significant difference was noted regarding the frequency of production of antibodies directed against UP and NUP (table IA).

\section{Rapid Decrease of Antibody Titer}

In 17 of 125 subjects with 18 episodes (13.6\%), the antibody titers decreased within 8 weeks (table IB). There was no significant difference between infections due to UP or NUP. The findings of a representative case are recorded in table III. It may be seen that $E$. coli O66 was isolated in large numbers and the antibody titer against this microorganism was high. A substantial reduction in titer occurred within 2 weeks and a further reduction during the ensuing 2 months. The specificity of this decrease in antibody titer was evident from the fact that a second infection, associated with the presence of E.coli $\mathrm{O} 40$ in the urine, was followed by an increase in the titer of homologous antibodies.

\section{Duration of Antibody Response}

As seen in table IB, 62 out of 125 subjects $(49.6 \%)$ had an antibody response lasting for less than 1 year and $63(50.4 \%)$ for more than 1 year; 49 patients had antibody responses to two or more organisms, one response lasting less than and the other more than 1 year.

Data on the relation between serogroups of E.coli and duration of antibody response are presented in table IV. A longer lasting antibody response occurred more frequently with E.coli O8 (NUP) than with E.coli O6, O7, and $\mathrm{O} 75$ (UP).

\section{Recall Antibody Response}

In 9 of 125 subjects (7.2\%), a second antibody response to the identical microorganism could be doc- 
Antibody responses of children with urinary tract infections

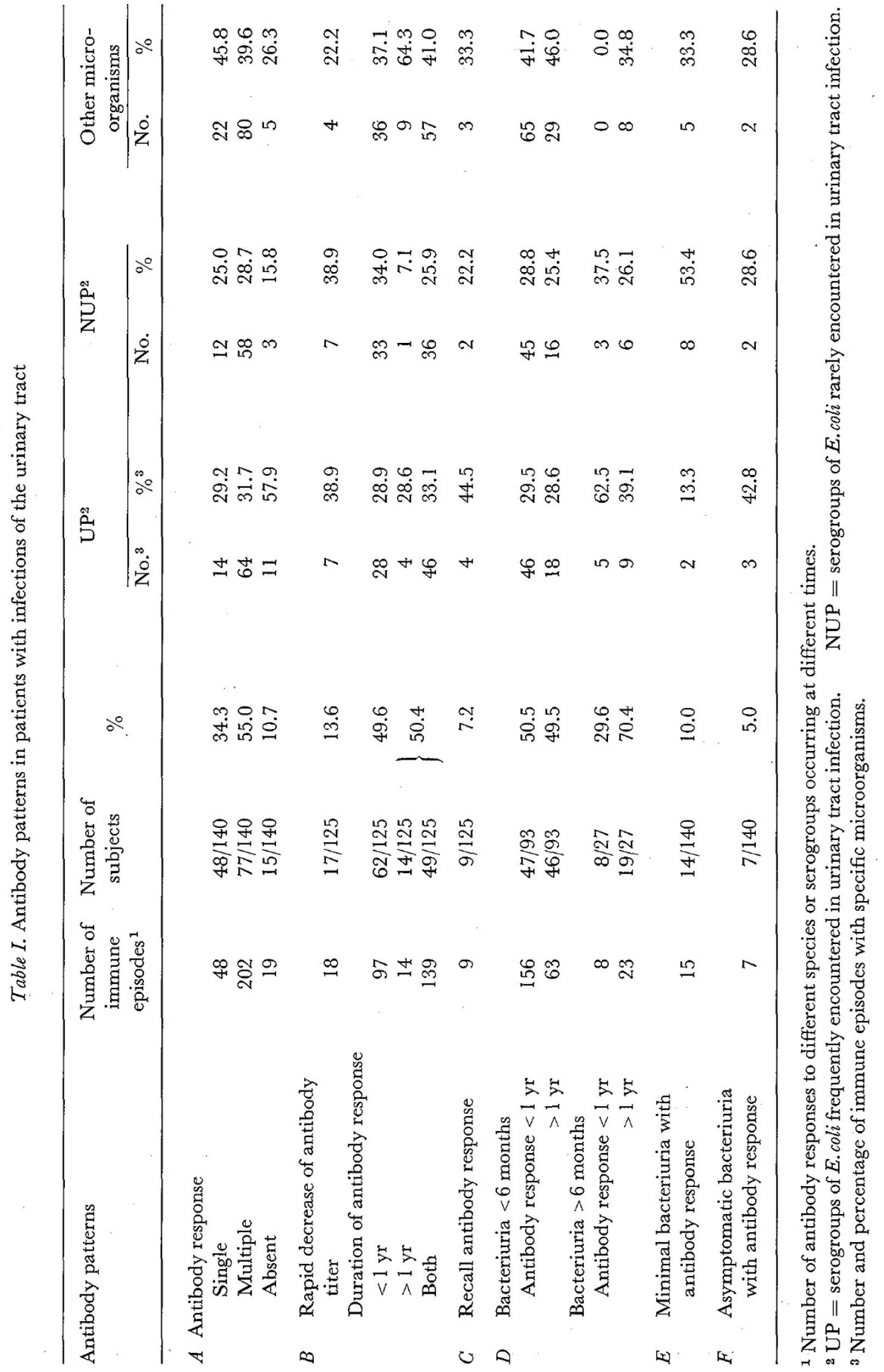


Table II. Serogroups of E. coli and antibody response

\begin{tabular}{lccccccr}
\hline Antibody & \multicolumn{7}{c}{ E.coli serogroups } \\
\cline { 2 - 8 } response & $\mathrm{O} 1$ & $\mathrm{O} 4$ & $\mathrm{O} 6$ & $\mathrm{O} 7$ & O75 & O8 & Total \\
\hline Positive & 18 & 14 & 18 & 16 & 9 & 12 & 87 \\
& $(90 \%)$ & $(67 \%)$ & $(51 \%)$ & $(89 \%)$ & $(50 \%)$ & $(100 \%)$ & 37 \\
Negative & 2 & 7 & 17 & 2 & 9 & 0 & 37 \\
& $(10 \%)$ & $(33 \%)$ & $(49 \%)$ & $(11 \%)$ & $(50 \%)$ & $(0 \%)$ & 124 \\
Total & 20 & 21 & 35 & 18 & 18 & 12 & 124 \\
\hline
\end{tabular}

Table III. Rapid decrease of antibody titers

\begin{tabular}{llccc}
\hline Dates & E.coli O66 & $\begin{array}{c}\text { Bacterial } \\
\text { counts/ml }\end{array}$ & $\begin{array}{c}\text { E.coli O66 } \\
\text { Antibody titers } \\
\text { (reciprocal) }\end{array}$ & $\begin{array}{c}\text { E.coli O40 } \\
\text { Antibody titers } \\
\text { (reciprocal) }\end{array}$ \\
\hline $7-26-67$ & Positive & $>10^{6}$ & 1,280 & 40 \\
$8-7-67$ & Negative & 160 & 40 \\
$10-4-67$ & Negative & 40 & 320 \\
\hline
\end{tabular}

Table IV. Serogroups of E.coli and duration of antibody response

\begin{tabular}{lrrrrrrr}
\hline $\begin{array}{l}\text { Duration of } \\
\text { antibody response, yr }\end{array}$ & $\mathrm{O} 1$ & $\mathrm{O} 4$ & $\mathrm{O} 6$ & $\mathrm{O} 7$ & $\mathrm{O} 75$ & $\mathrm{O} 8$ & Total \\
\hline$>1$ & 8 & 7 & 2 & 3 & 2 & 8 & 30 \\
$<1$ & 10 & 7 & 16 & 13 & 7 & 4 & 57 \\
Total & 18 & 14 & 18 & 16 & 9 & 12 & 87 \\
\hline
\end{tabular}

Table $V$. Recall antibody response

\begin{tabular}{llccc}
\hline Dates & Urine cultures & $\begin{array}{c}\text { Bacterial } \\
\text { counts/ml }\end{array}$ & $\begin{array}{c}\text { E. coli O6 } \\
\text { Antibody titers } \\
\text { (reciprocal) }\end{array}$ & $\begin{array}{c}\text { E.coli O7 } \\
\text { Antibody titers } \\
\text { (reciprocal) }\end{array}$ \\
\hline $3-27-65$ & E.coli O6 & $>10^{6}$ & $<20$ & 160 \\
$3-29-65$ & - & & 80 & 320 \\
$5-5-65$ & Negative & & 320 & 80 \\
$7-21-65$ & Negative & $>10^{8}$ & 20 & 80 \\
$9-20-65$ & E.coli O7 & & - & - \\
$10-7-65$ & Negative & 20 & 2,560 \\
\hline
\end{tabular}

Table VI. Persistent bacteriuria without antibody response

\begin{tabular}{llcc}
\hline Dates & $\begin{array}{l}\text { E.coli } \text { O6 } \\
\text { urine cultures }\end{array}$ & $\begin{array}{c}\text { E.coli } \text { O6 } \\
\text { Antibody titers } \\
\text { (reciprocal) }\end{array}$ & $\begin{array}{c}\text { E.coli O 103 } \\
\text { Antibody titers } \\
\text { (reciprocal) }\end{array}$ \\
\hline $12-63$ & Positive $\left(>10^{6}\right)$ & $<20$ & 40 \\
$12-63$ to $6-64$ & Positive 9 times & $<20$ & 80 \\
$6-64$ to $11-64$ & Positive 7 times & $<20$ & 80 \\
$12-64$ & E.coli O $103\left(>10^{6}\right)$ & $<20$ & 320 \\
$1-65$ to $4-68$ & Positive 48 times & $<20$ & $320-160$ \\
\hline
\end{tabular}


umented after a significant fall in the titers of antibodies following the first infection (table IC). The interval was as short as 3-6 months and as long as 2-4 years. Such recall responses were encountered with UP, NUP, and other microorganisms. The bacteriologic and immunologic data of a representative case are summarized in table $\mathrm{V}$ and indicate that a significant antibody response occurred to E.coli O6 recovered from the urine in March 1965. During the ensuing 5 months this antibody titer decreased substantially, and a recall response to $E$. coli was clearly documented between July and October 1965, at a time when E. coli O7 was present in the urine in significant numbers. The specificity of the antibody response was documented by inhibition tests with $E$. coli $\mathrm{O} 6$.

\section{Bacteriuria and Antibody Response}

The studies of KAss [14] have revealed that a statistical relation exists between the number of bacteria per millimeter of urine from the bladder and the presence of urinary tract infection. In the majority of instances, urine from the bladder of infected subjects contains at least $10^{4}$, and frequently more than $10^{5}$, viable bacteria per millimeter. One might expect, therefore, that a relation also exists between the degree and duration of significant bacteriuria and the antibody response. As shown in table ID, no difference was noted in the duration of the antibody response for more or less than 1 year between the group of 219 subjects with bacteriuria lasting less than 6 months and the group of 31 patients with bacteriuria of more than 6 months' duration. Some unexpected patterns, however, have been encountered; namely, persistent bacteriuria without antibody response, persistent elevated antibody titers in the absence of continued bacteriuria, antibody response at time of minimal bacteriuria, and antibody response during asymptomatic bacteriuria.

Persistent bacteriuria without antibody response. The failure to detect an antibody response in the presence of long-lasting bacteriuria with a single serogroup of $E$. coli was an unexpected occurrence. The data from a representative case are summarized in table VI. Antibodies were not detected during 4 years, although E. coli $\mathrm{O} 6$ was isolated from 64 urine specimens. That the failure of this antibody response was not due to immunologic incompetence was deduced from the observation that the patient produced antibodies against E.coli $\mathrm{O} 103$ following infection with this microorganism in 1964. Further, no antibodies were detected with antigen prepared from E.coli $\mathrm{O} 6$ isolated from other patients. Another possibility to be considered was that IgG antibodies of low hemagglutination activity instead of IgM antibodies may have been synthesized by this patient. If this pattern of antibody response was responsible for the absence of detectable hemagglutina-
TableVII. Persistently elevated antibody titers in the absence of persistent bacteriuria with homologous $E$. coli ${ }^{1}$

\begin{tabular}{llcc}
\hline Dates & E.coli O7 & $\begin{array}{r}\text { Bacterial } \\
\text { counts/ml }\end{array}$ & $\begin{array}{c}\text { Antibody titers } \\
\text { (reciprocal) }\end{array}$ \\
\hline $4-65$ & Positive & $>10^{6}$ & 5,120 \\
$7-65$ & Negative & & 1,280 \\
$10-65$ & Negative & & 640 \\
$6-66$ & Negative & & 320 \\
$8-67$ & Negative & & 320 \\
\hline
\end{tabular}

${ }^{1}$ E. coli $\mathrm{O} 7$ present on 1 occasion and absent in 23 cultures.

Table VIII. Group-specific antibody response at time of minimal or absent bacteriuria

\begin{tabular}{|c|c|c|c|}
\hline \multirow[t]{2}{*}{ Dates } & \multicolumn{2}{|c|}{ Cultures } & \multirow{2}{*}{$\begin{array}{c}\text { Antibody titers } \\
\text { E.coli } \mathrm{O} 73\end{array}$} \\
\hline & Organism & Count/ml & \\
\hline $1-67$ & Sterile & - & $<20$ \\
\hline $2-67$ & Sterile & - & $<20$ \\
\hline $3-67$ & Sterile & - & 40 \\
\hline $4-67$ & E.coli O 73 & 500 & 160 \\
\hline $5-67$ & E.coli O 73 & $>10^{6}$ & 80 \\
\hline
\end{tabular}

tion, this patient, and others, represents an unusual pattern of urinary tract infection.

Persistent elevated antibody titers in the absence of continued bacteriuria. Persistent antibody production observed in a patient in the absence of continued bacteriuria is illustrated in table VII. It may be seen that the initial bacteriuria in this case was associated with the production of homologous antibodies in high titer. Although E.coli $\mathrm{O} 7$ was not isolated during the ensuing 2 years, the antibody titer, although reduced, remained at significantly elevated levels.

Antibody response at time of minimal bacteriuria. Minimal bacteriuria $(<10,000$ colonies $/ \mathrm{ml})$ with a significant antibody response was observed in 14 subjects $(10 \%)$ with 15 immune episodes (table IE). Since the number of observations was small, it was not certain whether the distribution between UP and NUP was significant.

Antibody response during asymptomatic bacteriuria. Asymptomatic bacteriuria with immune response was noted in 14 subjects. There was no significant difference in the increase of titers of the antibody to UP and NUP (table IF). In all instances the asymptomatic infection either followed or preceded overt disease. 


\section{Discussion}

The antibody response of 140 children with infection of the urinary tract $(26 \%$ acute and $74 \%$ with chronic or recurrent infection) was determined over a period of 1-7 years. The antibody response to the $\mathrm{O}$ antigens of gram-negative bacteria was determined by the passive hemagglutination test on serially obtained specimens of serum. This approach was used rather than comparing antibody titers of these patients with those found in healthy subjects, since 'normal' titers vary significantly with age. The hemagglutination procedure measures preferentially, though not exclusively, $\operatorname{IgM}$ antibodies [11]. Since the initial report in 1955 [19], this method has been widely employed, both in this country and abroad $[1,2,6,9,10,12,15,18,32,37,38$, $40,41]$. Also, as reported by Holmaren and HANSON [17], this test may detect related $\mathrm{K}$ antigens. As a result of the present investigations, the following patterns have emerged: 1) single and multiple antibody responses; 2) antibody production for short and long periods of time; 3) recall antibody response; 4) significant bacteriuria with or without antibody response; 5) prolonged bacteriuria without antibody response; 6) minimal bacteriuria following or preceding infection with antibody response; and 7) asymptomatic bacteriuria with antibody response.

A specific $\mathrm{O}$ antibody response could be documented in 121 out of 140 patients ( $89 \%$ ), representing $250 \mathrm{im}$ munologic episodes. Approximately one-third of all patients had a single antibody response and slightly over one-half had multiple responses. This high frequency was probably related to the fact that the majority of patients had chronic or recurrent infection, that multiple serum specimens were available for study, and that all isolates from urine cultures were used as antigens. Utilizing the conventional bacterial agglutination test, Percival et al. [30] detected an antibody response in $93 \%$ of 41 patients with acute pyelonephritis. In the latter study, comparison was made between titers of antibody in patients and those of control subjects.

Previous studies, summarized by NeTER [21], have revealed that certain serogroups of E.coli occur with greater frequency in urinary tract infection, although this preponderance was not noted in another series [33]. These serogroups are referred to as UP, and the others as NUP. No substantial difference has been noted in the present investigation in the antibody response of patients to UP, to other typable E.coli serogroups (NUP), or to other gram-negative bacteria, and the percentages of single and multiple responses were similar (table I).

One of the major problems of chronic or recurrent infection of the urinary tract is the differentiation be- tween persistence of the same microorganism or the acquisition of new strains. Only with complete identification of the urinary isolates, such as serogrouping and typing, can a reasonable answer be obtained. In adults, Turak et al. [35] found that the same microorganism was recovered from 52 out of 65 recurrences in patients with renal bacteriuria, but in only 11 out of 38 recurrences in 25 subjects with bladder bacteriuria. In 20 children with 102 episodes of urinary tract infection, different organisms or serotypes of E. coli were isolated from $70 \%$ of the patients, suggesting that reinfection was twice as common as relapse [5]. Study of the antibody response affords an additional opportunity to document the acquisition of new strains. Previously, Neter et al. [25] reported on multiple antibody responses. In the present series, multiple antibody responses to antigenically unrelated species of serogroups were almost twice as frequent as single responses (table I).

A recall antibody response should occur in subjects with relapse, provided that the antibody titers against the microorganism had decreased prior to the recurrence. Indeed, in the present series, such a recall antibody response was documented in nine subjects.

For the past decade, quantitation of bacteria present in urine from the bladder, has been employed routinely as an aid to diagnosis. In the majority of patients with definitive urinary tract infection the count of bacteria per millimeter exceeds $10^{4}$ and often $10^{5}$. This significant bacteriuria is often associated with a specific $\mathrm{O}$ antibody response. In some patients, however, the number of bacteria in the urine is much lower. As shown in the present study, a specific immune response to minimal bacteriuria with overt disease could be documented in $10 \%$ of the subjects. In addition, $5 \%$ of the patients with asymptomatic bacteriuria produced the corresponding $\mathrm{O}$ antibodies. It should be emphasized that in these subjects asymptomatic bacteriuria was a phase of chronic or recurrent infection, either following or preceding overt disease. Previously, ANDERSEN et al. [3] observed a rise in antibody titers with minimal bacteriuria in three subjects. A similar response was reported [30] in $18 \%$ of 86 patients by demonstrating antibody titers above those of normal controls, and in bacteriuric, pregnant women, higher titers of antibodies were observed against their own organisms than in noninfected subjects prior to overt pyelonephritis [10].

It was not surprising that patients with documented urinary tract infection did not develop antibodies against the infecting microorganism. Among 26 subjects with bacteriuria of more than 1 year duration, 13 episodes occurred in the absence of an antibody response. In one patient, $E$.coli $\mathrm{O} 6$ was recovered no less than 64 times and yet the corresponding $\mathrm{O}$ antibody 
titer during this observation period did not exceed $1: 20$ (table VI). This failure of a specific immune response was not due to immunologic incompetence as some patients responded to an infection with another serogroup of E.coli or developed anti-H and $\mathrm{O}$ antibodies following typhoid vaccination or a result of lack of available serum specimens at suitable times. Whether this persistent bacteriuria without antibody response is similar to the postulated colonization of the intestinal tract in the absence of antibody production [23] remains to be determined. ANDERsEn et al. [3] considered the possibility that failure of the immune response might be related to certain characteristics of the bacterial strains. It is unlikely that this explanation pertains to the present observations, because the E.coli strains involved were both typable and typical and belonged to different $\mathrm{O}$ groups.

It can be expected that infection of the urinary tract of limited duration is followed by a decrease in antibodies. Indeed, a rapid decrease within 8 weeks was observed in 17 patients and similar observations were previously reported [3, 30, 39]. As shown, antibody titers may remain elevated in subjects whose bacteriuria had terminated for more than 1 year (table VII). Since $\mathrm{O}$ antibody titers decreased substantially within a few months following recovery from Shigella and Salmonella infections [24], it may be expected that persistence of high titers was due to continued stimulation of antibody production by antigen, although not necessarily by viable bacteria. If this was the case, immunologic studies might provide a possible indicator of continued disease, particularly since ANGell et al. [4] reported the existence of active chronic pyelonephritis without evidence of bacterial infection. It is conceivable that antibodies detected by the hemagglutination test used in the present study may have pathogenic significance, for immune hemolytic disease can be elicited by these antibodies in the rabbit [34].

Current information [3, 13, 30, 39] suggests that immune response occurs much more frequently in pyelonephritis than in cystitis. Localized bladder pouch infection of dogs, however, in the proven absence of renal infection, stimulates a marked antibody response [7]. UEHLING et al. [36] showed that it was not cystitis per se but the kind and degree of disease of the bladder that determined the immune response. Infection associated with a foreign body in the bladder led to a significantly higher antibody response than simple infection, and the introduction even of killed bacteria into the bladder wall also was followed by an antibody response. Thus, future studies in man should be directed toward relating the pathologic processes of cystitis in man to the systemic and local immune response. The classes of immunoglobulins produced, either locally or systemically, as well as their biologic activities in patients with urinary tract infection, also require further inquiry. Local production of antibodies in the urinary tract has recently been documented [28, 29]. Determination of the serum antibody response is a valuable tool in elucidation of the incompletely understood processes of urinary tract infection in man.

\section{References and Notes}

1. Andersen, H.J.: Glinical studies on the antibody response to $E$. coli $\mathrm{O}$-antigens in infants and children with urinary tract infection, using a passive haemagglutination technique. Acta paediat., Uppsala 180: 5 (1967).

2. Andersen, H.J.: Antikörperreaktionen bei verschiedenen Arten von Harnwegsinfektionen; in: Losse and Kienitz: Pyelonephritis, p. 97 (Thieme, Stuttgart 1967).

3. Andersen, H.J.; Hanson, L.A.; Lincoln, K.;

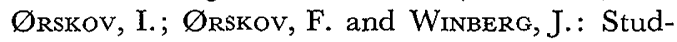
ies of urinary tract infections in infancy and childhood. IV. Relation of the coli antibody titre to clinical picture and to serological type of the infecting Escherichia coli in acute, uncomplicated urinary tract infections. Acta paediat., Uppsala 54: 247 (1965).

4. Angell, M.E.; Relman, A.S. and Robbins, S. L.: 'Active' chronic pyelonephritis without evidence of bacterial infection. New Engl. J.Med. 278: 1303 (1968).

5. Bergström, T.; Lincoln, K.; Ørskov; F.; Ørskov, I. and WinBerg, J.: Studies of urinary tract infections in infancy and childhood. VIII. Reinfection vs. relapse in recurrent urinary tract infections. Evaluation by means of identification of infecting organisms. J.Pediat. 71: 13 (1967).

6. Garter, M.J.; Ehrenkranz, N.J.; Burns, J. and CASSADY, J. C. : Serological responses to heterologous Escherichia serogroups in women with pyelonephritis. New Engl. J. Med. 279: 1407 (1968).

7. Darwish, M.E.; Staubitz, W.J.; Scheuller, E. F.; Rubin, M. I. and Neter, E. : Antibody response of dogs to experimental infection of bladder pouch. Invest. Urol. 6: 66 (1968).

8. EDwards, P.R. and EwrNG,W.H. : Identification of enterobacteriaceae (Burgess Publishing, Minneapolis 1962).

9. Ehrenkranz, N.J. and Garter, M.J.: Immunologic studies in urinary tract infections. I. The hemagglutination response to Escherichia $\mathrm{O}$ antigens in infections of varying severity. J. Immunol. 92: 798 (1964).

10. Elder, H.A. and KAss, E. H.: Serological changes 
in bacteriuria of pregnancy. Antimicrobial Agents Chemother. 1966: 24.

11. Hanson, L. A. and Winberg, J.: Demonstration of antibodies of different immunoglobulin types to the O-antigen of the infection E.coli strain in infants and children with pyelonephritis. Nature, Lond. 212: 1495 (1966).

12. Hauschka, M.S.; Neter, E. and Rubin, M.I.: Urinary tract infection in children. II. Identification of Escherichia coli $\mathrm{O}$ antibodies in serum of patients. Amer.J. Dis. Child. 109: 238 (1965).

13. Hewstone, A.S. and Whrtaker, J.: The correlation of ureteric urine bacteriology and homologous antibody titer in children with urinary infection. J.Pediat. 74: 540 (1969).

14. KAss, E.H.: Bacteriuria and the diagnosis of infections of the urinary tract with observations on the use of methionine as a urinary antiseptic. Arch. intern. Med. 100: 709 (1957).

15. Kienitz, M. and LÜCKE, P.: Erregerspezifische Antikörper bei Pyelonephritis; in: Losse and Krenitz: Pyelonephritis, p. 79 (Thieme, Stuttgart 1967).

16. Kunin, G. M.; Beard, M. V. and Halmagyi, N. E. : Evidence for a common hapten associated with endotoxin fractions of E.coli and other enterobacteriaceae. Proc. Soc. exp. Biol., N.Y. 111: 160 (1962).

17. Holmgren, J. and Hanson, L. A.: Immunodiffusion studies on Escherichia coli. 2. Characterization of antigens used for passive haemagglutination with O6 strain as model. Acta path. microbiol.scand. 77: 727 (1969).

18. Narbutowicz, B.: Bacteriologic and diagnostic studies of the urinary tract. Diagn. Lab. 5: 45 (1969).

19. Needel, M.H.; Neter, E.; Staubitz, W.J. and BINGHAM, W.A.: The antibody (hemagglutinin) response of patients with infections of the urinary tract. J. Urol. 74: 674 (1955).

20. Neter, E. : Bacterial hemagglutination and hemolysis. Bact. Rev. 20: 166 (1956).

21. Neter, E.: Bacteriology and immune response in urinary tract infections. Pediat. Clin. Nth. Amer. 11: 517 (1964).

22. NETER, E.: Indirect bacterial hemagglutination, and its application to the study of bacterial antigens and serologic diagnosis. Path. Microbiol. 28: 859 (1965).

23. Neter, E.; Drislane, A.M.; Harris, A.H. and JANSEN, G. T.: Diagnosis of clinical and subclinical salmonellosis by means of a serologic hemagglutination test. New Engl. J. Med. 261: 1162 (1959).

24. Neter, E. and Dunphy, D.: The duration of the hemagglutinin response in the serum of children with shigellosis and salmonellosis. Pediatrics 20: 78 (1957).

25. Neter, E.; Steinhart, J.; Galcagno, P.L. and RuBin, M.I. : Urinary tract infection in children. I. Studies on antibody response; in Kass Progress in pyelonephritis, p. 129 (Davis, Philadelphia 1965).

26. Neter, E.; Westrhal, O.; Lüderitz, O. and GoRzYNSKI, E.A.: The bacterial hemagglutination test for the demonstration of antibodies to enterobacteriaceae. Ann. N.Y.Acad.Sci. 66: 141 (1956).

27. Neter, E. ; Zalewski, N.J. and Ferguson, W.W.: Escherichia coli hemagglutinin response of adult volunteers to ingested E.coli O55 $\mathrm{B}_{5}$. Proc. Soc. Biol., N.Y. 82: 215 (1953).

28. Pazin, G.J. and Braude, A. I. : Immobilizing antibodies in pyelonephritis. J.Immunol. 102: 1454 (1969).

29. Pearsall, N. N. and Sherris, J. G.: The demonstration of specific urinary antibodies in urinary tract infections caused by gram-negative bacilli. J. Path. Bact. 91: 589 (1966).

30. Percival, A.; Brumfitt, W. and de Louvots, J.: Serum-antibody levels as an indication of clinically inapparent pyelonephritis. Lancet ii: 1027 (1964).

31. Pfaundler, M.: Eine neue Form der Serumreaktion auf Coli- und Proteusbacillosen. Cent. Bakt. Parasitenk. 23: 131 (1898).

32. SArTo, I. : Serological study of chronic pyelonephritis. Especially on the diagnosis value of the estimation of enterobacterial common antibody response. Fukushima J. Med. Sci. 14: 45 (1967).

33. Schwarz, H.; Sctrmer, H.K.A.; Post, B. and EHLERs, B.: Correlation of Escherichia coli occurring simultaneously in the urine and stool of patients with clinically significant bacteriuria: serotyping with group-specific O antisera. J.Urol. 101: 379 (1969).

34. Shumway, G.N.; Bokkenheuser, V.; Pollock, D. and Neter, E.: Survival in immune and nonimmune rabbits of ${ }^{51} \mathrm{Cr}$-labeled erythrocytes modified by bacterial antigen. J. Lab. clin. Med. 62: 600 (1963).

35. Turck, M.; Ronald, A.R. and Petersdorf, R. G. : Relapse and reinfection in chronic bacteriuria. II. The correlation between site of infection and pattern of recurrence in chronic bacteriuria. New Engl. J. Med. 278: 422 (1968).

36. Uehling, D.T.; Barnhart, D.D. and Seastone, C. V.: Antibody production in urinary bladder infection. Invest. Urol. 6: 211 (1968).

37. Vosti, K.L.; Monto, A.S.; Older, J.J. and Rantz, L. A.: The serologic specificity of crude and purified antigen extracts of Escherichia coli in hemagglutination reactions with rabbit and human antisera. J. Immunol. 93: 199 (1964). 
38. Wankowicz, Z.; Narbutowicz, B.; Kozaczek, W. and Piotrowska, E.: Diagnostic value of the passive hemagglutination test in pyelonephritis. Pol. Arch. Med.Wewn. 41: 531 (1968).

39. Williamson, J.; Brainerd, H.; Scaparone, M. and CHUEH, S.P.: Antibacterial antibodies in coliform urinary tract infections. Arch.intern. Med. 14: 222 (1964).

40. WingerG, J.; Andersen, H.J.; Hanson, L. A. and Lincoln, K.: Studies of urinary tract infections in infancy and childhood. I. Antibody response in different types of urinary tract infections caused by coliform bacteria. Brit.med. J. ii: 524 (1963).

41. Wyszynska, T.; Narbutowicz, B.; SoldaJ, H. and Wencel, J.: Immunological response to urinary tract infections in children. Pediat. Polska 43: 1347 (1968).

42. Supported by National Institute of Child Health and Human Development Research Grant no. HD00294, and National Institute of Allergy and Infectious Diseases Research Grant no. AI 00658.

43. The authors express appreciation to Drs. G.N. Scatchard, P. L. Galcagno, W.J. Rahill, S.J. Yaffe, W.J. Staubitz, and C. E. Hollerman, who participated in the study of the patients, and to Miss Phyllis Miner, Mrs. Helga von Langendorff, Mrs. Doris Schroeter, Mrs. Dessie MaCartan, and Miss Loretta Alicandro for excellent technical assistance. They also are indebted to the National Communicable Disease Center, Atlanta, Georgia, for the diagnostic antisera. Informed consent was obtained for all subjects in this study.

44. Requests for reprints should be addressed to: Erwin Neter, M.D., Children's Hospital, 219 Bryant Street, Buffalo, NY 14222 (USA).

45. Accepted for publication February 18, 1970. 